\title{
Estimation of vitamin $D_{2}$ intakes in diverse European populations based on serum 25-hydroxyvitamin $\mathrm{D}_{2}$ data
}

\author{
K.G. Dowling ${ }^{1}$, M. Kiely ${ }^{1,2}$ and K.D. Cashman ${ }^{1,3}$ on behalf of the ODIN Workpackage 1 \\ consortium \\ ${ }^{1}$ Cork Centre for Vitamin D and Nutrition Research, School of Food and Nutritional Sciences, ${ }^{2}$ INFANT Research \\ Centre and ${ }^{3}$ Department of Medicine, University College Cork, Ireland
}

Unlike vitamin $\mathrm{D}_{3}$, which is made by the action of UVB sunlight on the skin and also obtained in the diet, vitamin $\mathrm{D}_{2}$ only comes from dietary sources ${ }^{(1)}$. The few items in the human food chain that contain significant amounts of vitamin $\mathrm{D}_{2}$ are supplements, fortified foods, ultraviolet B (UVB) light exposed mushrooms, and food made with UVB exposed bakers' yeast. Despite the widely held assumption that dietary exposure to vitamin $\mathrm{D}_{2}$ is limited, we have recently reported that $78 \%(n=884)$ of participants in the National Adult Nutrition Survey (NANS) in Ireland had serum 25-hydroxyvitamin $\mathrm{D}_{2}\left(25(\mathrm{OH}) \mathrm{D}_{2}\right)$ concentrations above the limit of quantification ${ }^{(1)}$. Data on serum $25(\mathrm{OH}) \mathrm{D}_{2}$ in other European populations is lacking. The objective of this study was to generate serum $25(\mathrm{OH}) \mathrm{D}_{2}$ data and estimates of vitamin $\mathrm{D}_{2}$ intakes using subsets of serum samples from 14 European population studies.

Bio-banked sera (each $n=100-170$ ) from Ireland [adults, children], Germany [adults, children and adolescents], Norway [adolescents, adults], Netherlands [adults, older adults], Finland [ethnic minority adults], Iceland [older adults], Denmark [children] and multi-country [adolescents] were analysed as part of the European Commission-funded ODIN project (www.odin-vitd.eu/) using our liquid chromatography tandem mass spectrometry method which measures 25 -hydroxyvitamin $\mathrm{D}_{3}$ and $25(\mathrm{OH}) \mathrm{D}_{2}$ simultaneous$1 \mathrm{y}^{(1)}$. Data from 9 randomized controlled trials which tested the efficacy of UVB-exposed mushroom products or vitamin $\mathrm{D}_{2}$-enhanced beverages in improving vitamin $\mathrm{D}$ status ${ }^{(2,3,4)}$, showed a mean response in serum $25(\mathrm{OH}) \mathrm{D}_{2}(\mathrm{nmol} / \mathrm{L})$ to ingested vitamin $\mathrm{D}_{2}(\mu \mathrm{g})$ of $0.95 \mathrm{nmol} / \mathrm{L}$ per $\mu \mathrm{g} /$ day. This response factor was used to estimate median intakes in each of the 14 populations.

\begin{tabular}{|c|c|c|c|c|}
\hline \multirow[b]{2}{*}{ Country (no. of studies) } & \multicolumn{2}{|c|}{ Serum $25(\mathrm{OH}) \mathrm{D}_{2}(\mathrm{nmol} / \mathrm{L})^{1}$} & \multicolumn{2}{|c|}{ Estimated vitamin $D_{2}$ intake $(\mu \mathrm{g} / \mathrm{d})^{1}$} \\
\hline & Median & SD & Median & $\mathrm{SD}$ \\
\hline Ireland (2) & $2 \cdot 5$ & $0 \cdot 7$ & $2 \cdot 6$ & 0.05 \\
\hline Germany (2) & $1 \cdot 5$ & $0 \cdot 1$ & 1.6 & $0 \cdot 1$ \\
\hline Norway (2) & $1 \cdot 5$ & $0 \cdot 5$ & 1.5 & $0 \cdot 5$ \\
\hline Multi-country (1) & $1.4^{*}$ & - & 1.5 & - \\
\hline Greece (2) & $1 \cdot 3^{*}$ & $0 \cdot 2$ & $1 \cdot 3$ & $0 \cdot 2$ \\
\hline Netherlands (2) & $1 \cdot 2^{*}$ & $0 \cdot 3$ & $1 \cdot 3$ & $0 \cdot 3$ \\
\hline Denmark (1) & $1 \cdot 1 *$ & - & $1 \cdot 2$ & - \\
\hline Finland (1) & $1.0^{*}$ & - & $1 \cdot 1$ & - \\
\hline Iceland (1) & $0 \cdot 8^{*}$ & - & $0 \cdot 9$ & - \\
\hline
\end{tabular}

${ }^{1}$ Estimates are presented as the average (SD) of medians from the individual population studies within a country where there were two studies.

$*$ Value above the limit of detection $(0.44 \mathrm{nmol} / \mathrm{L})$ but below limit of quantitation $(1.43 \mathrm{nmol} / \mathrm{L})$.

Median concentrations of serum $25(\mathrm{OH}) \mathrm{D}_{2}$ ranged from $0 \cdot 8-2 \cdot 5 \mathrm{nmol} / \mathrm{L}$ in these European populations, while median vitamin $\mathrm{D}_{2}$ intakes were estimated to be in the range $0 \cdot 9-2 \cdot 6 \mu \mathrm{g} / \mathrm{day}$ (see table), with Ireland having the highest estimated median intake of $2.6 \mu \mathrm{g} /$ day. In conclusion, based on serum $25(\mathrm{OH}) \mathrm{D}_{2}$ concentration data, European populations have exposure to vitamin $\mathrm{D}_{2}$ in their diet. The exact dietary sources of vitamin $\mathrm{D}_{2}$ in the European food chain needs to be investigated.

1. Cashman KD, Kinsella M, McNulty BA et al. (2014) Br J Nutr 112, 193-202.

2. Cashman KD, Kiely MK, Seamans KM, Urbain P (2016) J Nutr 146, 565-575.

3. Biancuzzo RM, Young A, Bibuld D et al. (2010) Am J Clin Nutr 91, 1621-1626.

4. Fisk CM, Theobald HE, Sanders TAB (2012) J Nutr 142, 1286-1290.

Supported by funding from the European Commission: ODIN (Food-based solutions for optimal vitamin D nutrition and health through the life cycle; Contract code 613977). 